\title{
URGENSI PENGUASAAN BAHASA ARAB DALAM STUDI ISLAM DI INDONESIA
}

\author{
Satrio \\ STAIN Sultan Abdurrahman Kepulauan Riau \\ satrio@stainkepri.ac.id
}

\begin{abstract}
ABSTRAK
Makalah ini hendak mengupas peranan penting bahasa Arab dalam studi Islam. Hal ini berangkat dari kenyataan bahwa bahasa Arab memiliki fungsi sebagai bahasa agama, bahasa komunikasi, bahasa peradaban dan bahasa ilmu pengetahuan. Pengaruh Islam dan bahasa Arab juga begitu terasa di Nusantara, khususnya tanah Melayu dengan hadirnya aksara arab melayu. Dalam penelitian ini ditemukan betapa pentingnya penguasaan bahasa Arab dalam studi Islam sebagai bagian dari pengembangan keilmuan. Kenyataannya saat ini, istilah bahasa Inggris lebih dominan dalam penggunaan istilah ilmiah dalam kajian studi Islam di Indonesia dibandingkan dengan bahasa Arab. Maka para pengajar dan pelajar studi Islam wajib menguasai istilah-istilah yang khusus dari bahasa Arab sebagai penguat sekaligus pembeda dari kajian-kajian ilmu umum. Adapun metode penguatan istilah-istilah ilmiah bahasa ini bisa menggunakan metode pembiasaan, yakni bentuk pengulangan yang dilakukan secara terprogram maupun spontan dalam penggunaan istilah-istilah ilmiah bahasa Arab. Di sini penulis menawarkan tiga metode pembiasaan, yakni metode pembiasaan dalam proses belajar, metode pebiasaan dalam penulisan naskah ilmiah dan atau buku ajar, serta metode pembiasaan dalam kegiatan-kegiatan ilmiah. Dengan pembiasaan, maka fungsi bahasa Arab sebagai bahasa ilmu pengetahuan akan mendapatkan posisi yang layak dalam studi Islam.
\end{abstract}

ABSTRACT: This paper aims to examine the important role of Arabic in Islamic studies. This departs from the fact that Arabic has a function as the language of religion, the language of communication, the language of civilization and the language of science. The influence of Islam and Arabic is also felt in the archipelago, especially Malay land with the presence of Malay Arabic characters. In this study it was found that the importance of mastering Arabic in Islamic studies as part of scientific development. In fact today, the term English is more dominant in the use of scientific terms in the study of Islamic studies in Indonesia compared to Arabic. So the instructors and students of Islamic studies must master the specific terms of Arabic as reinforcement as well as differentiators from general science studies. The method of strengthening scientific terms of this language can use habituation methods, namely the form of repetition carried out programmed and spontaneous in the use of scientific terms in Arabic. Here the author offers three methods of habituation, namely the method of habituation in the learning process, the habitual method of writing scientific texts and or textbooks, and methods of habituation in scientific activities. With habituation, the function of Arabic as a language of science will get a decent position in Islamic studies.

Keyword: Bahasa Arab Ilmiah, Pebiasaan Bahasa, Studi Islam

\section{Pendahuluan}

Kehadiran Islam di Nusantara sangat kuat pengaruhnya terhadap perkembangan bahasa Arab. Lebih-lebih lagi, para pendakwah yang menyiarkan agama Islam di Nusantara merupakan penutur bahasa Arab aktif, seperti dari Jazirah Arab dan Hadramaut, yang datang berdagang sekaligus menyebarkan agama. Misi dagang yang disertai dengan misi dakwah ini, telah melahirkan sebuah tradisi berbahasa baru yang dikenal di kalangan kaum terdidik, yakni bahasa Arab. Dengan mendalami bahasa Arab maka akan bisa menyelami ajaran agama Islam dengan baik sebab sumber ajaran agamanya berbahasa Arab, yakni AlQuran dan Sunnah. Dua sumber itu hanya dapat dipahami bila kemampuan penguasaan bahasa pengkaji sangat baik. Apalagi, dalam praktik ibadah, seperti salat dan berdoa, bahasa Arab menjadi bagian penting. Hal ini mendorong ada upaya masyarakat untuk mengenal bahasa Arab lebih baik lagi dengan tujuan bisa meresapi makna dari kandungan 
doa-doa yang dipanjatkannya, termasuk hingga saat ini.

Hingga kini, bahasa Arab juga selalu mendapatkan tempat bagi para pengkaji ilmu-ilmu keislaman (islamic studies), baik di pesantren, madrasah, hingga perguruan tinggi agama Islam. Kehadiran lembaga pendidikan yang fokus pada kajian keislaman menuntut penguasaan bahasa bagi pelajar-pelajarnya. Di pesantren dikenal dengan pengajian kitab kuning. Maksud dari kitab kuning sendiri yakni kitab berbahasa Arab yang tidak disertai dengan harkat dalam membaca dan sebagain besar dari kitab-kitab tersebut dicetak menggunakan kertas warna kuning. Mampu membaca kitab kuning, seringkali dianggap sejalan dengan kemampuan dalam berbicara atau komunikasi verbal berbahasa Arab. Padahal, pada kenyataanya banyak yang mampu membaca kitab kuning, tidak cukup baik dalam berbicara menggunakan bahasa Arab.

Dari kenyataan itu, yang paling penting dari penguasaan bahasa Arab ialah bagi pengkaji studi Islam. Di kalangan pengkaji keilmuan Islam, setidaknya diperlukan suatu penguasaan terhadap bahasa Arab agar bisa terus mengembangkan khazanah pengetahuan Islam. Sebagaimana dalam sejarah, pada khalifah Harun al-Rasyid (786-809 M) dan al-Ma'munt (813-833 M) berkuasa, penerjemahan beragam ilmu ke dalam Arab telah memberikan kontribusi yang besar terhadap perkembangan pengetahuan Islam. Karya-karya dari filosof Yunani, ilmuwan Persia dan India menjadi sumber penting penerjemahan yang dilakukan oleh dua khalifah itu. Menurut Muhbib Abdul Wahab, yang mengutip dari Abduh al-Hilwu dan Bahzad Jabir, di antara buku yang diarabkan saat itu adalah al-Tasyrîh (Pembedahan) karya Jalinus, al-Handasah (Arsitektur) karya Plato, al-Majesti karya Ptolemios, dan al-Sama wa al-Alam karya Aristoteles. ${ }^{1}$ Karya terjemahan itu menambah

1 Muhbib Abdul Wahab, "Peran Bahasa Arab dalam Pengembangan Ilmu dan Peradaban Islam," ARABIYAT: Jurnal Pendidikan Babasa Arab dan banyak jumlah litelatur yang bisa dikaji oleh ilmuan muslim sehingga sehingga perkembangan khazanah keilmuan Islam juga tumbuh pesat.

Demikian juga dalam sejarah Islam di Nusantara yang tumbuh pesat setelah banyak cendekia muslim menguasi bahasa dan melakukan penerjamahan teks-teks Arab ke melayu. Bahasa Arab sebagai bahasa agama tidak kemudian mepengaruhi tradisi tulis di tanah Melayu. Maka lahirkan aksara Arab Melayu, yakni bahasa Melayu yang tulisannya menggunakan aksara Arab. Di Jawa dikenal dengan Arab Pegon. Di melayu sendiri dulunya disebut dengan tulisan Jawi. Perkembangan bahasa Arab dengan aksara Arab untuk bahasa Melayu ini juga memberikan sumbangsih penting bagi pertumbuhan kajian islam di semanjung melayu. Banyak naskah-naskah klasik melayu berbahasa Arab Melayu atau Jawi hingga bisa dilihat hingga saat ini.

Perkembangan studi Islam saat ini juga berkembang pesat. Hal ini diiringi dengan tumbuhnya perguruan tinggi Islam atau pun fakultas agama Islam di Indonesia. Namun penguasaan bahasa Arab tidak sebanding dengan penguasaan bahasa asing lainnya, seperti bahasa Inggris, sehingga hal ini berdampak pada kurang menyatunya antara istilah khas keilmuan Islam dengan istilah dalam bahasa asing lain. Para pelajar dan mahasiswa di perguruan tinggi juga banyak tidak menguasai dasar-dasar dan istilah-istilah Arab dalam kajian Islam. Dari beberapa penelitian sebelumnya disebutkan, bahwa urgensi pengetahuan bahasa Arab ini juga semakin penting di tengah integrasi keilmuan yang begitu gencar dan berkembang pesat pada perguruan tinggi Islam. Menurut Alan Budi Kusuma, ada dua sebab mengaja perlu telaah lebih lanjut terhadap perkembangan bahasa di Indonesia khususnya, yakni karena bahasa Arab telah memiliki ruang yang kondusif bagi perkembangannya dan masyarakat Indonesia

Kebahasaaraban 1, no. 1

https://doi.org/10.15408/a.v1i1.1127. 
telah cukup akrab dengan bahasa Arab. ${ }^{2}$ Namun, ia juga menilai bahwa terdapat kesenjangan antara teori dan praktek atau antara potensi dan aktualisasi, maka kesenjangan yang sama juga terjadi dalam posisi bahasa Arab di Indonesia.

Berangkat dari itulah, maka penulis memandang penting untuk menelaah lebih lanjut perihal urgensi pengetahuan dan penguasaan bahasa Arab di kalangan pengkaji studi Islam, baik di kalangan pengajar ataupun dosennya maupun di kalangan pejalar maupun mahasiswanya. Studi lebih menitikberatkan pada konseptual perkembangan bahasa sebagai ilmu liguistik dan bahasa sebagai sarana ilmu pengetahuan. Hal ini berkesesuaian dengan bahsaa Arab sebagai bahasa bahasa internasional dan lebih-lebih lagi bahasa yang adaptif untuk pengkajian studi Islam. Dalam penelitian ini, akan menggunakan pendekatan sejarah untuk mengetahui perkembangan bahasa Arab dan urgensinya dalam penguatan studi Islam yang telah berkembang di Indonesia khususnya.

\section{Linguistik Fungsional Bahasa Arab}

Linguistik merupakan ilmu yang mencoba mengkaji secara obyektif terhadap bahasa. Hal ini diperlukan untuk menghilangkan prasangka sosial dan rasial terhadap bahasa itu sendiri. Membedakan linguistik sebagai sebuah disiplin ilmu pengetahuan dari beberapa disiplin ilmu lain yang melihat bahasa dari sudut eksternal juga merupakan suatu bentuk upaya obyektif. Pengkajian bahasa secara eksternal, berarti bahasa diselidiki dalam hubungannya dengan berbagai fenomena lainnya. Maka, tidak heran apabila dalam perkembangannya, ilmu bahasa ini juga turut memiliki disiplin ilmu baru, di antaranya sosiolinguistik, psikolinguistik, dan neurolinguistik. ${ }^{3}$ Sosiolinguistik misalnya, muncul seiring dengan upaya mempela jari hubungan dan

2 Alam Budi Kusuma, "Transformasi Pengajaran Bahasa Arab di Indonesia," Al-Manar 5, no. 1 (2016): 23.

${ }^{3}$ Shkholid Nasution, Pengantar Linguistik Bahasa Arab (Malang: Lisanul Arabi, 2017). saling pengaruh antara perilaku bahasa dengan perilaku sosial. Psikolinguistik muncul seiring dengan upaya mempelajari hubungan antara bahasa dengan perilaku dan akal budi manusia. Sementara neurolinguistik muncul seiring dengan upaya mempelajari prakondisi neurologis (urat saraf) untuk perkembangan bahasa. Oleh karena linguistik mengkaji bahasa secara an sich, maka ia pun bersifat umum bisa mendapatkan kajian dar.

Dalam kaitan ini, ilmu linguistik sering juga disebut dengan linguistik umum. Keumuman lingusitik ini dikemukakan oleh Verhaar, sebagaimana dikutip S Nasution, yaitu "linguistik tidak hanya menyelidiki satu langue (bahasa) tertentu tanpa memperhatikan ciri-ciri bahasa lain."

Harus diakui bahwa setiap bahasa memiliki nilai-nilai universal dan juga karakteristik tersendiri. Keuniversalan yang terdapat di dalam semua bahasa inilah yang menjadi kajian linguistik. Sedangkan karakteristik tersendiri, merupakan bidang kajian tersendiri sebagai sosiolinguistik dan psikolinguistik. Seiring dengan itu, setiap linguis hendaknya menguasai satu atau lebih bahasa asing, dan yang lebih baik jika bahasa asing yang dikuasai itu adalah bahasa yang tidak serumpun dengan bahasa kebangsaannya. Karena itulah, perlu suatu penguatan dalam setiap bahasa agar memiliki karakteristik tersendiri.

Secara umum, linguistik juga memiliki prinsip sebagai bentuk keuniversalannya. Menurut Dudung Hamdun ada delapan prinsip dasar linguistik bila di lihat dari berbagai sisinya. ${ }^{5}$ Prinsip meliputi sistem, vocal, susunan lambang, unik, dan lain sebagainya. Berikut masing-masing prinsip dasar tersebut, yakni (1) bahasa adalah suatu sistem karena memiliki suatu sistem polapola yang kompleks dan suatu struktur dasar dengan ketentuan tersendiri; (2) bahasa adalah vokal, yang berarti hanya ucapan dan ujaran sajalah yang mengandung segala tanda 
utama sesuatu bahasa; (3) bahasa tersusun dari lambang-lambang arbitrer yang berarti bahwa hubungan antara lambang dan makna juga bersifat arbitrer; (4) setiap bahasa bersifat unik, mempunyai ciri-ciri khas sehingga tidak ada dua bahasa yang mempunyai perangkat pola-pola yang sama, bunyi-bunyi yang sama, kata-kata atau sintaksis yang sama; (5) bahasa dibangun dari kebiasaan-kebiasaan, yang artinya bahwa sangat bergantung pada tingkatan kebiasaan; (6) bahasa berfungsi untuk komunikasi, baik berupa ucapan maupun tulisan; (7) bahasa berhubungan dengan kebudayaan tempatnya berada; (8) bahasa itu bisa berubah, baik yang mencakup kosa kata, bunyi-bunyi bahasa, bentuk kata, bentuk kalimat, dan Iain-lain.

Prinsip dasar tersebut juga terdapat pada bahasa Arab. Dalam konteks perubahan, bahasa Arab juga bisa menerima bahasa serapan, khususnya yang tidak memiliki akar kata asli. Dalam konteks bahasa Arab, ia tidak hanya produk kebudayaan dan peradaban manusia, melainkan juga sebagai bahasa agama bagi umat Islam. Hal inilah yang membuat bahasa Arab menjadi spesial di kalangan kaum muslim. Secara fungsi, bahasa Arab juga tidak hanya sekadar bahasa sebagai alat komunikasi antar orang per orang, melainkan juga komunikasi dengan Allah. Unsur-unsur penting yang demikian itu memang dimiliki bahasa Arab sehingga perkembangannya bisa eksis sampai saat ini.

Secara lebih spesifik, sebagaimana menurut Umam yang dikutip oleh $\mathrm{S}$ Nasution, ${ }^{6}$ fungsi-fungsi bahasa secara umum adalah alat komunikasi, alat berpikir, berfungsi dalam upaya meyakinkan orang lain atau mempengaruhi sekelompok tertentu; individu atau masyarakat, berfungsi sebagai lambang agama, ${ }^{7}$ pendukung yang mutlak

${ }^{6}$ Nasution, Pengantar Linguistik Bahasa Arab. h.8

7 Bahasa Ibrani, misalnya, menjadi lambang bagi agama Yahudi, bahasa Latin adalah lambang bagi agama Katolik, bahasa Inggris banyak dipakai Agama Protestanisme, dan bahasa Arab adalah lambang bagi agama Islam, karena Alquran sebagai kitab suci umat Islam diturunkan dengan berbahasa Arab. terhadap keseluruhan perkembangan ilmu pengetahuan manusia, berfungsi sebagai media dalam menumbuh kembangkan peradaban, dan berfungsi sebagai alat pemersatu. $^{8}$ Apabila diperhatikan, bahasa Arab sudah memenuhi sebagian besar dari fungsi-fungsi tersebut. Hal ini terbukti bahwa Arab saat ini juga menjadi bagian dari pengetahuan, khususnya di bidang studi Islam. Dari sisi fungsionalnya ini pula, maka bahasa bisa menjadi lahan kajian di kalangan peneliti dan akademisi.

Secara umum, kajian bahasa dapat dikelompokkan ke dalam dua perspektif, yaitu linguistik formal dan linguistik fungsional. Linguistik formal memandang bahasa sebagai suatu struktur yang dapat dianalisis ke dalam unit-unit bahasa yang lebih kecil. Sedangkan linguistik fungsional memandang bahasa sebagai sistem tanda yang dapat dianalisis berdasarkan struktur bahasa dan pemakaian bahasa. Pemakaian bahasa berkait dengan mengapa dan bagaimana bahasa digunakan. Dalam perspektif linguistik fungsional, bahasa adalah sistem arti dan sistem lain (yakni sistem bentuk dan ekspresi) untuk merealisasikan arti tersebut. ${ }^{9}$

Kajian ini berdasar pada dua konsep yang membedakan LFS dengan aliran linguistik lain, yaitu (a) bahasa merupakan fenomena sosial yang wujud sebagai semiotik sosial dan (b) bahasa merupakan teks yang berkonstrual (saling menentukan dan merujuk) dengan konteks sosial. Dalam ilmu pengetahuan, transformasi ilmu membutuhkan bahasa dalam interaksi. Sama halnya dengan fungsional bahasa dalam konteks sosial, bahasa dalam konteks ilmu pengetahuan juga memiliki fungsional. Dalam konteks sosial, ada tiga pengertian

8 Bahasa Indonesia, misalnya, bisa menjadi salah satu alat pemersatu bangsa dengan kebinekaanya yang demikian kompleks. Bahkan dapat dikatakan bahwa perbedaan bahasa lebih potensial menimbulkan konflik dari pada perbedaan suku, ras, golongan, bahkan agama.

9 Amrin Saragih, Bahasa dalam Konteks Sosial (Medan: FBS Unimed, 2002). 
terintegrasi di dalam konsep fungsional ini. Pertama, fungsi bahasa berdasarkan tersetruktur berdasarkan kebutuhan manusia. Kedua, bahasa sering kali memiliki multifungsi dalam kehidupan manusia. Ketiga, unit yang lebih kecil dari bahasa memiliki keterkaitan dengan atau menjadi bagian dari unit yang lebih besar. Maka dari itu, sebuah grup, preposisi, atau klausa sisipan, berfungsi dalam klausa kompleks untuk membangun kompleksitas tersebut dalam sebuah teks. ${ }^{10}$ Sedangkan bahasa yang berfungsi dalam ilmu pengetahuan juga memerlukan suatu sistem yang baru.

Kajian juga ini melihat bagai perkembangan fungsional bahasa Arab sebagai bahasa ilmu pengetahuan dalam studi Islam di lembaga pendidikan islam, baik berupa madrasah maupun perguruan tinggi. Apalagi, saat ini perkembangan integrasi keilmuan telah begitu pesat sehingga setiap kajian memiliki keterkaitan dengan pondasi yang kokoh. Misalnya, kajian hukum Islam tidak lagi sebatas pengenalan halal dan haram, melainkan mampu memotret kebutuhan hukum Islam bagi kalangan muslim di Indonesia. Demikian juga dengan perkembangan tarbiyah atau pendidikan Islam dengan tantangan dan problematika yang terus berubah-ubah seiring dengan perkembangan zaman. Dalam hal ini seperti inilah, bahasa Arab sebagai bagian ilmu pengetahuan perlu mendapatkan perhatian penting agar tidak tercerabut dari asalnya, yakni studi Islam.

\section{Perkembangan Bahasa Arab: Dari Timur Tengah ke Tanah Melayu}

Perkembangan awal bahasa Arab bermula dari jazirah Arab. Para peneliti mengidentifikasi bahasa Arab sebagai turunan dari bahasa Semit. ${ }^{11}$ Terlepas suku

10 Bahagia Saragih, "Linguistik Fungsional: Dimensi Dalam Bahasa," BAHAS 27, no. 03 (2016): 7, https://doi.org/10.24114/bhs.v27i3.5672.

11 Lihat Latifah Salim, "Sejarah Pertumbuha dan Perkembangan Bahasa Arab," Diwan: Jurnal Bahasa dan Sastra Arab 3, no. 1 (20 Juli 2017): 77, https://doi.org/10.24252/diwan.v3i1.2928. mana yang menggunakannya terlebih dahulu, tetapi perkembangan bahasa Arab yang dipakai saat ini diketegorikan dua kelompok, yakni bahasa Arab Fusha dan Ammiyah. Dua istilah yang terakhir ini sangat menentukan arah perkembangan bahasa Arab hingga saat ini, bahkan juga telah menjadi obyek penelitian panjang di kalanga peneliti linguistik. Saat ini, bahasa Arab merupakan salah satu bahasa internasional sebagaimana ditetapkan oleh PBB karena kurang lebih 20 negara. Bagian ini akan menyajikan perihal perkembangan bahasa Arab dari negara asalnya hingga sampai ke Tanah Melayu.

Bahasa Arab fusha adalah ragam bahasa yang ditemukan di dalam Al-Quran, hadis Nabi dan warisan tradisi arab. Biasanya, bahasa arab ini digunakan dalam hal-hal formal dan resmi serta penulisan prosa dan syair. Sedangkan bahasa amiyah adalah ragam bahasa yang digunakan untuk urusan-urusan biasa sehari-hari, lumrahnya digunakan dalam percakapan dan karya-karya tidak resmi. Sebelum kedatangan Islam, masyarakat Arab mengenal stratafikasi kefasihan bahasa. Kabilah yang dianggap paling fasih di banding yang lain adalah Quraisy yang dikenal sebagai surat al-Arab (pusatnya masyarakat Arab). Kefasihan bahasa Quraisy ini terutama ditunjang oleh tempat tinggal mereka yang secara geografis berjauhan dengan negara-negara bangsa non-Arab dari segala penjuru. ${ }^{12}$ Dalam perkembangannya, bahasa Arab Quraisy ini pulalah yang dipakai al-Quran dan juga menjadi standar Hadis.

Pelajaran tentang bahasa semakin mendapat tempat di kalangan pemeluk Islam karena banyak penyesuaian dan upaya standarisasi bacaraan al-Quran dan Hadis. Pengembang bahasa Arab tidak hanya datang dari orang Arab, melainkan juga dari masyarakat non-Arab. Seperti imam Sibawaih (w. $130 \mathrm{H}$ ) yang menjadi tokoh penting dalam peletakan rumusan gramatikal bahasa Arab dasar. Karangannya juga menjadi

12 Achmad Tohe, "Bahasa Arab Fusha dan Amiyah serta Problematikanya," Bahasa dan Seni 33, no. 2 (t.t.): 15 . 
rujukan penting di kalanga santri hingga saat ini. Pola yang digunakan oleh penerus ajaran Sibawaihi juga telah berkembang pesat hingga melahirkan banyak bidang dan cabang dalam ilmu nahwu. Dasar-dasar bahasa ini juga menjadi perhatian di kalangan masyarakat non-Arab seiring dengan semakin berkembangannya ilmu pengetahuan alQuran dan Hadis, dua sumber utama dalam memahami Islam.

Pada perkembangan selanjutnya, bahasa Arab fusha juga telah menjadi bagian dari bahasa surat menyurat atau administrasi yang digunakan oleh kalangan penguasa muslim. Di masa khalifah Malik ibn Marwan, bahasa Arab diposisikan sebagai bahasa negara (dawlah Umayyah), khususnya sebagai bahasa resmi dan bahasa administrasi pemerintahan. Meskipun Arabisasi ini memang agak bernuansa politis, dampaknya cukup luas dan signifikan dalam pengenalan bahasa Arab. Akhirnya, bahasa Arab mampu mengungguli pengaruh bahasa Persia, Qibtia, dan bahasa Romawi sebagai bahasa administrasi. ${ }^{13}$ Secara perlahan, bahasa Arab mulai mengambil tempat sebagai bahasa internasional ketika itu, penggunanya tidak hanya kalangan Arab, melainkan sudah menyebar ke beberada daerah di jazirah Arab bahkan hingga Andalusia.

Pendirian Bait al-Hikmah oleh alMakmun menjadikan bahasa Arab sebagai bahasa politik sekaligus sebagai bahasa pendidikan, ilmu pengetahuan, dan kebudayaan. Dengan kata lain, wacana keilmuan dalam berbagai bidang (filsafat, teologi, tasawuf, bahasa, fiqh, kedokteran, kimia, optika, geografi, musik, matematika, Aljabar, Aritmatika, dan sebagainya) diekspresikan dan dikembangkan dengan menggunakan bahasa Arab, meskipun pengembang dan perumusnya bukan orang Arab. Sejak masa itu juga, umat Islam mendapati bahasa Arab tampil sangat elegan, fleksibel, dan bernilai sastra tinggi dalam mentransmisikan berbagai karya intelektual
Muslim dalam bentuk karya tulis, baik buku maupun manuskrip, yang hingga kini masih menjadi bahan kajian dan sumber inspirasi pemikiran Islam yang sangat berharga. Menurub Muhbib, posisi bahasa Arab sebagai bahasa ilmu pengetahuan Islam, bahasa pendidikan, dan kebudayaan pada masa keemasan Islam tersebut dipandang penting sebagai "prestasi ganda", yaitu prestasi Islam dan jaga bahasa Arab. ${ }^{14}$

Dalam konteks ini, dapat ditegaskan bahwa bahasa Arab mempunyai posisi sangat penting dan strategis dalam pengkajian dan pengembangan ilmu-ilmu keislaman, bahkan dalam pengembangan peradaban Islam. Cendekia dan para pengembang bahasa Arab ini juga banyak datang dari luar Arab dan bahkan karya-karya mereka ditulis dalam bahasa Arab, seperi al-Farabi (w.339 H), Ibn Sina (w. 428 H), Ibn Miskawaih (932-1030 M), al-Ghazali (w. 1111 M). Hal ini telah menandakan bahwa waktu itu bahasa Arab merupakan bahasa ilmu pengetahuan, yakni bukan semata-mata bahasa komunikasi harian antarpenuturnya, melainkan bahasa ilmu pengetahuan yang mampu mewadahi dan mentransmisikan wacana pemikiran dan karya-karya keilmuan. ${ }^{15}$

Sedangkan sejarah perkembangan bahasa Arab di Indonesia di mulai sejak masyarakat Indonesia mulai memeluk Islam. Mereka belajar bahasa Arab semata-mata sebagai alat untuk mempelajari dan memperdalam studi Islam. Penegasan yang penting dari sejarah ini ialah bahwa, kehadiran Islam tidak hanya membawa agama melainkan juga membawa ilmu penegtahuan. Agama sebagai norma dan doktrin yang harus dipatuhi oleh para pemeluknya pada satu sisi dan di sisi lain juga membawa ilmu pengetahuan agar supaya umat muslim bisa bergama dengan nyaman. Oleh sebab itu, pelajaran agama Islam di Indonesia erat kaitannya dengan pelajaran bahasa Arab. Sebagaimana alasan pada bagian awal, bahwa sumber ajaran Islam
13 Wahab, "Peran Bahasa Arab dalam Pengembangan Ilmu dan Peradaban Islam," h.6

$$
\begin{aligned}
& { }^{14} \text { Ibid. } \\
& { }^{15} \text { Ibid. }
\end{aligned}
$$


adalah al-Quran dan Sunnah yang semuanya dalam bahasa Arab. Untuk bisa memahaminya, maka diperlukan kemampuan berbahasa Arab.

Pelajaran bahasa Arab di nusantara ini diajarkan oleh para guru dengan pendekatan ilmu agama, bukan sekadar ilmu bahasa. Lokasi yang menjadi tempat belajar bisa di surau, masjid, pondok pesantren, maupun madrasah-madrasah. Tradisi itu berkembang dari Aceh hingga Gorontalo. Tidak hanya di Indonesia, melainkan juga di semenjung Malaysia, dan bahkan daerah yang dulunya di sebut Nusantara. Menariknya, kerajaan-kerajaan Islam justru telah memfasilitasi adanya pelajaran agama (islamic studies) dengan memasukkan bahasa Arab sebagai kurikulum dasarnya. Di Aceh misalnya, terdapat delapan kerajaan Islam, tetapi tingkatan institusi pendidikannya sama. Menurut Kusuma, ketika itu, di setiap desa memberikan program pendidikan dasar yang disebut Meunasah dan setiap masjid menyediakan pendidikan menengah yang disebut Rangkang. Program pendidikan lanjut, disebut dayang, terdapat di setiap Naggroe atau wilayah uleebalang, dan Dayah Teungku Chik. Program diploma diberikan di pusat kerajaan. Program pendidikan universitas diberikan di Jami'ah Baiturrahman di Banda Aceh, yang kemudian dialihkan ke dalam Masjid Raya Baiturrahman oleh Sultan Iskandar Muda, dan juga dipakai sebagai pusat kegiatan pengetahuan. Kusuma menyimpulkan, kuat dugaan pelajaran bahasa Arab telah diberikan pada tingkat dayang atau bahkan Rangkang. ${ }^{16}$

Contoh lain yakni pengajaran bahasa arab di kerajaan Islam Minangkabau (1500 M/1650 M). Di sana, pada setiap negeri (desa) didirikan sebuah masjid untuk shalat Jum'at, dan di setiap kampung didirikan surau sebagai tempat mengaji al-Quran dan shalat lima waktu. Menurut tradisi yang berkembang, anak yang berusia tujuh tahun harus dipisah dari ibunya dan bermalam di surau sambil belajar al-Quran. Menurut Kusuma, inilah yang dinamakan Pengajian Quran. Setamat dari sini, beberapa murid meneruskan ke jenjang Pengajian Kitab pada tuan Syekh di sebagian negeri (desa). Di tingkat inilah bahasa Arab diajarkan dan menjadi dasar pengajaran ilmu-ilmu keislaman lainnya. Akan tetapi, karena jumlah murid yang terus bertambah, sistem yang berjalan ketika itu, para murid atau santri tidak langsung belajar pada syeikh atau guru besar, melainkan pada guru-guru pembantu. Sedangkan yang belajar pada tuan Syeikh hanyalah guru-guru tua, sebutan bagi guruguru bantu yang mengajar murid-murid. Bila pada tingkat pertama, murid diajar satu demi satu, maka pada tingkat kedua murid diajar dengan sistem halaqah, duduk berlingkar menghadap guru. Menurut Kusuma, sistem ini berlangsung sampai tahun 1908 atau 1909, saat madrasah-madrasah dengan sistem klasikal muncul, dipelopori oleh Syekh Abdullah Ahmad yang pada tahun 1909 mendirikan Madrasah Adabiyah. ${ }^{17}$

Hal demikian ini juga tidak jauh berbeda dengan keberadaan di kerajaan RiauLingga-Johor-Pahang. Ketika itu pusat studi Islam berada di pulau Penyengat dengan tokoh centralnya Raja Ali Haji. Yang tidak kalah menarik dari perkembangan bahasa Arab di Nusantara, khsusunya di tanah Melayu ialah penggunaan huruf arab sebagai alat penulisan bahasa Melayu. Hingga saat ini, bahasa melayu yang ditulisakan dengan huruf Arab dikenal kenal Arab Pegon, huruf Jawi, dan Arab Melayu. Arab Pegon biasanya disebutkan dalam tradisi pesantren di Jawa dan banyak berkembang atau dipengaruhi oleh para santri yang menimba ilmu ke Mekah dan Madinah. Sedangkan istilah huruf Jawi saat ini banyak digunakan oleh masyarakat Semenajung Melayu seperti Malaysia, Singapura, Brunei Darussalam dan Pattani. Sedangkan Arab Melayu dikenal di
16 Alam Budi Kusuma, "Transformasi Pengajaran Bahasa Arab di Indonesia.” h. 6-7
${ }^{17}$ Ibid. 
kalangan masyarakat melayu di Riau dan Kepulauan Riau. ${ }^{18}$

Dalam perkembangannya, tulisan Arab Melayu menjadi bahasa administasi resmi yang digunakan oleh kerajaan-kerajaan di Nusantara. Bahkan, beberapa sekolah juga telah menerapkan kurikulum pelajaran Arab Melayu. Misalnya, pada Kurikulum HIS, dalam Statuta 1914 No. 764, masih dipakai dalam mata pelajaran bahasa Melayu. ${ }^{19}$ Kehadiran bahasa Melayu di HIS ini memiliki dua posisi ganda, yakni sebagai bahasa komunikasi dan administrasi yang berlaku bagi pribumi dan juga sebagai tulisan yang masih banhyak digunakan oleh sebagai kerajaan-kerajaan ketika itu yang masih menggunakan arab melayu. Yang tidak kalah menarik ialah banyak santri dan pengkaji keilmuan Islam di sekolah-sekolah non formal (baca: pesantren) yang juga menaruh minat untuk melanjutkan pendidikan ke Timur Tengah, khususnya Mekah dan Madinah sebagai pusat kajian Islam kala itu.

Sementara terkait perkembangan pembelajaran bahasa Arab di nusantara, menjadi pelajaran ilmu alat yang paling penting bagi yang hendak melanjutkan ke beberapa perguruan tinggi di Timur Tengah. Mereka belajar bahasa Arab bukan sekadar sebagai alat atau perangkat untuk mendalami kitab-kitab, melainkan juga sebagai tujuan supaya bisa melanjutkan pendidikan ke Timur Tengah. Ketika usai menimba ilmu, banyak di antara mereka yang tergolong ahli bahasa Arab dan mampu menggunakan bahasa Arab secara aktif, baik menyimak (mendengar), berbicara, dan menulis. Setelah mereka pulang ke tanah air, mereka mengusahakan pembaharuan metode untuk pengajaran bahasa Arab. Dengan metode tersebut, mereka berhasil menumbuhkan bahasa Arab untuk dipelajari juga sebagai tujuan, yakni untuk membentuk ahli-ahli bahasa Arab dan menghasilkan alumni yang

18 Dalam naskah ini, istilah yang digunakan ialah Arab Melayu.

19 S Nasution, Sejarah Pendidikan Idonesia (Jakarta: Bumi Aksara, 1995), h.114. mampu menggunakan bahasa Arab secara aktif sebagai alat komunikasi untuk berbagai keperluan. Hal ini juga mendorong para ahli bahasa arab di Indonesia terdorong untuk segera mengajarkan bahasa Arab sebagai tujuan menjadi alat sekaligus tujuan untuk mencapai cita-cita melanjutkan pendidikan ke perguruan tinggi di Timur Tengah. Pengertian bahasa Arab dengan metode dan untuk tujuan tersebut sudah mulai dilaksanakan di beberapa madrasah, baik di Sumatra seperti madrasah Thawalib, di Jawa seperti pondok Darussalam Gontor (Ponorogo).

Perguruan tinggi ilmu keislaman yang juga tumbuh pesat tidak lain adalah suatu bentuk perkembangan pendidikan studi islam yang modern. Status Sekolah Tinggi Agama Islam (STAI), Institus Agama Islam (IAI) dan juga Universitas Islam merupakan wadah pengembangan studi islam yang perlu memperhatikan pelajaran bahasa Arab sebagai fondasi untuk mempelajari beragam kajian dalam Islam. Dari gambaran di atas telah terlihat jelas betapa Islam dan bahasa Arab adalah bagian yang tidak terpisah sehingga dirasah al-islamiyah atau studi Islam sehingga mampu mengentarkan kajian keislaman tumbuh dan berkembang pesat. Pengaruh Islam dan ilmu pengetahuan Islam juga telah memberikan sumbangsih yang besar bagi peradaban Nusantara, khususnya di tanah Melayu. Maka, sudah sewajarnya apabila kemudian bahasa Arab menjadi elemen penting untuk setiap pengakaji dan pengajar studi Islam.

\section{Bahasa Arab Sebagai Syarat Penguasaan Studi Islam}

Perkembangan studi Islam menuntut para pelajar dan juga pengejar bisa menguasai bahasa Arab karena sumber-sumber asli ajaran Islam yakni al-Qur'an, hadits dan ilmuilmu keislaman tertulis dalam bahasa Arab. Apabila tidak menguasai bahasa Arab, maka akan sulit untuk mengkaji Islam dari sumber aslinya yang berasal dari bahasa Arab. Harus diakui bahwa fungsi bahasa Arab yang paling utama adalah sebagai alat komunikasi, baik 
antar individu sebagai masyarakat sebuah negara maupun individu sebagai pemeluk agama Islam. Ketika seseorang memiliki ide, selanjutnya ia berpikir tentang ide tersebut, dan muncul keinginan untuk menyampaiakn ide dan hasil pikirannya tersebut kepada orang lain, maka saat kondisi itu manusia membutuhkan alat komunikasi, yaitu bahasa. ${ }^{20}$

Menurut Asna Andriani, ada empat hal yang membuat bahasa Arab penting untuk dikuasai, ${ }^{21}$ yakni (1) sumber asli ajaran Islam al-Quran dan Hadits ditulis dalam bahsa Arab, (2) kitab-kitab karya ulamaulama besar yang mempengaruhi alur pemikiran umat Islam terutama di bidang tafsir, hadits, fqih, aqidah, tasawuf ditulis dalam bahasa Arab, (3) kajian ilmu keislaman akan semakin berbobot jika mengambil rujukan dari bahasa Arab, (4) banyak sarjana dari perguruan tinggi agama Islam yang tidak memiliki dasar pengetahuan bahasa Arab. Pendapat yang sama juga disampaikan Ubaid Ridho, yang menyatakan bahwa penting sekali untuk menguasai bahasa bagi setiap pengkaji studi Islam. ${ }^{22}$ Apalagi realita saat ini bahwa perguruan tinggi Islam juga telah menjadi pilihan di kalangan masyarakat yang ingin mendapatkan ilmu pengetahuan umum sekaligus ilmu agama.

Dari dua alasan di atas, argumen yang paling penting yang terkait dengan studi Islam yakni pengembangan ilmuan pengetauan sebagai jawaban atas perkembangan zaman. Aspek ilmu pengetahuan dan teknologi mengalami perkembangan seiring dengan perkembangan zaman. Dinamisasi peristiwa demi peristiwa

20 Imelda Wahyuni, "Bahasa Arab dalam Konteks Simbol Agama (Analisis Terhadap Tujuan Pembelajaran pada Perguruan Tinggi Islam)," Zawiyah 3, $\begin{array}{rrrr} & \text { no. } & 2 & \text { (2017): }\end{array}$ http://dx.doi.org/10.31332/zjpi.v3i2.720.

${ }^{21}$ Asna Andriani, "Urgensi Pendidikan Bahasa Arab dalam Pendidikan Islam," Ta'allum 3, no. 1 (2015):

https://doi.org/10.21274/taalum.2015.3.1.h.13.

22 Ubaid Ridlo, "Bahasa Arab dalam Pusaran Arus Globalisasi: Antara Pesimisme dan Optimisme," Ibya' al-Arabiyah 01, no. 02 (2015): h.213. dalam pengkajian ilmu pengetahuan telah terjadi sejak zaman dahulu, pengetahuan dan wawasan adalah tolok ukur kecerdasan seseorang, baik sebagai individu maupun sebagai bagian dari masyarakat secara utuh. Misalnya, saat ini sedang banyak kajian tentang ekonomi Islam dari berbagai kalangan di tengah ketidakadilan dari sistem ekonomi kapitalis. Maka, kajian ekonomi Islam juga mendapatkan tempat yang cukup penting dalam studi Islam, khususnya di Indonesia dan Malaysia. Sistem praktik muamalah Islam yang menjamin hak-hak para pihak supaya tidak ada yang dirugikan dan supaya bebas dari praktik riba menjadi fokus kajian. Dengan kajian yang intens dan fokus, maka banyak kajian ekonomi Islam kini menjadi kajian yang banyak peminat. Demikian juga dengan kajian hukum Islam yang terus tumbuh dan berkembang sesuai dengan kebutuhan hukum di tengah perubahan sosial masyarakat, seperti masukkan hukum perkawinan Islam dalam sistem hukum di Indonesia. Pengkajian ilmu pengetahuan Islam ini tidak terlepas dari kebutuhan terhadap bahasa Arab, baik dari karya klasik dan karya ilmiah modern yang bahasa Arab dan atau justru mengenalkan istilah bahasa yang konsistem sebagai istilah keilmuan dalam studi Islam. Dalam posisi inilah, perlunya para cendekia muslim untuk tetap mempertahankan istilah-istilah keilmuan menggunakan bahasa Arab. Oleh sebab itu pula, perlu memperdalam pengetahuan bahasa Arab. ${ }^{23}$

Sebagaimana telah disebutkan di awal, tradisi mempelajari bahasa Arab di Indonesia juga sudah sejak lama. Saat ini, bahasa Arab juga telah menjadi bagian dari kurikulum formal di sekolah-sekolah yang berbasiskan agama, baik di pesantren, dayah, ataupun yang serupa. Sedangkan di sekolah formal yang berbasiskan Islam, seperti Madrasah Ibtidaiyah, Madrasan Tsanawiyah, Madrasah Aliyah hingga perguruan tinggi,

23 Wahyuni, "Bahasa Arab dalam Konteks Simbol Agama (Analisis Terhadap Tujuan Pembelajaran pada Perguruan Tinggi Islam)," h. 84 
bahasa Arab menjadi bagian dari kurikulum umum yang harus di pelajari mahasiswa. Tujuan pembelajaran Bahasa Arab pada madrasah adalah untuk mengembangkan kemampuan dasar peserta didik dalam kehidupan pribadi, masyarakat sekitar dan masyarakat skala nasional dan internasional. Penentuan materi pembelajaran bahasa Arab seyogyanya selaras dengan kebutuhan dari segmen kehidupan tersebut dan juga penegasahan pada istilah-istilah yang berhubungan dengan ibadah. Apabila pembelajaran diisi dengan materi yang berlawanan arah dengan tujuan hidup atau realitas asas kebutuhan maka pembelajaran itu akan jauh dari konteks pembelajaran. ${ }^{24}$

Sedangkan kurikulum Perguruan

Tinggi Keagamaan Islam (PTKI) pada umumnya diselaraskan dengan kurikulum yang ada pada jenjang sekolah. Secara umum kebijakan pemerintah tentang bahasa Asing telah mewarnai segmen pendidikan di Indonesia, tujuan anasional pembelajaran bahasa Arab adalah untuk memotivasi kemampuan bahasa komunikatif peserta didik sehingga mereka mampu mewujudkan tujuan tersebut dalam beberapa bentuk, yaitu kemampuan berinteraksi dan komunikasi antara native dan non native speaker; memahami kebudayaan bahasa dan bangsa lain; dan memahami literatur berbahasa Asing (Arab) tentang kajian kebangsaan dan kebahasaan. ${ }^{25}$ Menurut Imelda, hal ini dapat dipahami sebagai bagian dari tujuan pembelajaran bahasa Arab pada seluruh jenjang pendidikan di Indonesia. ${ }^{26}$

Gambaran di atas mempertegas bahwa fungsi pengajaran bahasa Arab di Indonesia dimaksudkan untuk mencapai tiga tujuan. Pertama, sebagai alat untuk mempelajari dan memperdalam pengetahuan

24 Islami Suardi Wekke, Pembelajaran Bahasa Arab di Madrasah (Yogyakarta: Deepublish, 2017), h.87.

${ }^{25}$ Fathul Mujib, Rekonstruksi Pendidikan Bahasa Arab (Bandung: Pedagogia, 2010), h 84-85.

26 Wahyuni, "Bahasa Arab dalam Konteks Simbol Agama (Analisis Terhadap Tujuan Pembelajaran pada Perguruan Tinggi Islam)," h. 86
Islam seperti di madrasah-madrasah (negeri atau swasta), pondok pesantren, dan Perguruan Tinggi Agama Islam (negeri atau swasta). Kedua, sebagai tujuan, yaitu membentuk tenaga-tenaga ahli bahasa arab atau untuk menghasilkan alumni yang mampu menggunakan bahasa Arab secara aktif sebagai alat komunikasi untuk berbagai keperluan. Ketiga, untuk mengembangkan studi Islam agar semakin mampu memberikan kontribusi pada perkembangan peradaban dunia sesuai dengan cita-cita tatanan kehidupan bernilai Islami.

Sebelumnya telah dibahas juga tentang bukti-bukti bahwa bahasa Arab menjadi salah satu faktor kejayaan Islam pada masanya, pasalnya banyak buku berbahasa Asing yang diterjemahkan dalam bahasa Arab membantu para ilmuan untuk dapat menjadi handal dalam bidang mereka masing-masing. Adanya buku-buku berbahasa Arab membantu para ilmuan dalam mengkaji disiplin ilmu seperti kedokteran, perbintangan, sosial, politik dan ilmu-ilmu lainnya. Hal ini sejalan dengan pendapat tentang salah satu fungsi bahasa yaitu, educational use (bahasa digunakan sebagai bahasa pengantar pembelajaran). Maka dari itu, perlu metode yang sesuai agar bisa menjadikan bahasa Arab sebagai bahasa ilmu untuk studi Islam.

\section{Pembiasaan Bahasa Arab dalam Studi Islam}

Problem utama belajar bahasa asing ialah terletak pada ketidakbiasaan dalam penggunaan sehari-hari. Sedangkan bahasa termasuk ilmu praktis yang perlu selalu dilakukan secara berulang-ulang. Sama halnya ketika melihat anak-anak yang baru memulai memerhatikan lingkungan sekitar dengan mengafal nama-nama lalu mengucapkan, maka belajar bahasa asing juga perlu pengafalan dan praktik. Anak-anak yang telah menambah kosa kata, biasanya akan mengulang kosa kata yang baru itu hingga ia mendapatkan kosa kata pengganti lainnya. Maka dari itu, tidaklah berlebihan apabila 
problem utama penguatan studi Islam ialah penguasaan bahasa Arab.

Secara teoritis, pembiasaan dinilai efektif jika penerapannya dilakukan sejak awal. Adapun pengertian pembiasaan merupakan metode dalam pendidikan berupa proses penanaman kebiasaan. ${ }^{27}$ Menurut Ahmad Tafsir, inti dari pembiasaan ialah pengulangan. ${ }^{28}$ Pembiasaan ini juga memiliki banyak tokoh dan perkembangan teorinya masing-masing. Misalnya menurut teori pembiasaan operan oleh Skinner sebagaimana dikutip dari Syahid. Skinner membagi pembiasaan pemerolehan bahasa dalam dua perilaku. Pertama adalah perilaku jawaban (respondent behavior). Pada fase perilaku ini, reaksi timbul dengan sendirinya, segera setelah stimulus muncul. Kedua adalah perilaku operan (operant behavior). Pada fase ini stimulusnya tidak dibangkitkan, akan tetapi timbul dari organisme itu sendiri. Dalam hal ini Skinner mendasarkan teorinya pada prinsip bahwa jika suatu perbuatan mengakibatkan efek tertentu, kemungkinan bahwa jika perbuatan itu diulang akan memberi efek yang lebih atau justru jika ditinggalkan yang akan meningkat. Istilah ini bisa disebut pengulangan positif jika perbuatannya diulangi lebih sering, akan tetapi jika perbuatannya tidak diulangi maka disebut penguatan negatif. ${ }^{29}$

Ciri khas daripada metode pembiasaan adalah kegiatan pengualangan secara konsisten atas suatu hal yang sama supaya asosiasi antara srimulus dengan respon menjadi sangat kuat. Atau dengan kata lain, tidak mudah dilupakan. Dengan demikian, terbentuklah pengetahuan siap

27 Hery Nore Aly, Ilmu Pendidikan Islam (Jakarta: Logos Wacana Ilmu, 2013), h.184.

28 Ahmad Tafsir, Ilmu Pendidikan Islam dalam Perspektif Islam, 9 ed. (Bandung: PT Remaja Rosdakarya, 2010).

29 Ahmad Habibi Syahid, "Bahasa Arab Sebagai Bahasa Kedua (Kajian Teoritis Pemerolehan Bahasa Arab pada Siswa Non-Native)," ARABIYAT: Jurnal Pendidikan Babasa Arab dan Kebahasaaraban 2, no. $1 \quad$ (12 September 2015), https://doi.org/10.15408/a.v2i1.1797. atau keterampilan siap yang setiap saat siap untuk dipergunakan oleh yang bersangkutan. Bahkan, Nabi Muhammad juga sering melafalkan doa dengan doa yang sama sehingga beliau pun hafal. Para sahabat yang juga mendengar doa itu diucapkan berulangulang juga turut hafal. ${ }^{30}$ Maka, metode pembiasaan berbahasa Arab atau minimal menggunakan istilah Arab dalam studi Islam akan semakin menguatkan kajian studi Islam itu sendiri.

Problem yang dihadapi dalam pembelajaran dan pengkajian bahasa Arab di Indonesia juga komplek, satu di antaranya pilihan antara penggunaan bahasa fusha dan ammiyah. Sebagaimana telah diulas bagian awal, bahasa fusha memang cukup dominan dipelajari dan digunakan oleh kalangan pengkaji Islam di Nusantara. Sehingga yang berkembang saat inipun metode pembelajaran lebih dominan pada bahasa Arab fusha. Maka, saat ini yang berkembangkan ialah bahasa Arab modern. Kemunculannya ini dapat meredam pergolakan kebahasaan di kalangan bahasa Arab sendiri. Tetapi pergolakan tetap berlaku di kalangan muslimin dengan motif belajar bahasa Arab yang telah disebutkan di depan, yakni sebagai ilmu alat dan sakaligus sebagai tujuan. Oleh karena itu, perlu menguasai dua bahasa Arab, klasik dan modern. Walhasil, tujuan pengajaran bahasa Arab memiliki dua arah: bahasa Arab sebagai tujuan (memahami kemahiran berbahasa) dan bahasa Arab sebagai alat untuk menguasai pengetahuan lain dengan menggunakan wahana bahasa Arab. Di samping itu, jenis bahasa yang dipelajari meliputi dua bahasa: klasik dan modern. Penggabungan ini, di satu sisi, memiliki kelebihan, karena dapat meberdayakan kompetensi peserta didik secara komprehensif, namun di sisi lain, melahirkan ketidakmenentuan, karena keterbatasan sel-sel otak peserta didik untuk

30 Tafsir, Ilmu Pendidikan Islam dalam Perspektif Islam, h. 154.

31 Ahmad Tafsir, Ilmu Pendidikan Islam. H. 154 
mengakomodasi keduanya secara bersamaan. ${ }^{32}$ Tuntutan materi yang serba meliputi dan metodologi yang tentu saja bervariasi untuk sebagian kalangan dipandang melahirkan kegamangan antara keinginan untuk mempertahankan yang lama dan menggunakan yang baru.

Terlepas dari problem tersebut, keperluan penguasaan bahasa Arab di perguruan tinggi bukanlah semata untuk keperluan komunikasi, melainkan untuk penegasan tentang pentingnya bahasa Arab dalam studi Islam. Harus diakui bahwa ciri khas dari studi islam itu ialah istilah-istilah ilmiah yang diadobsi ke dalam bahasa Arab. Misalnya dalam kajian ekonomi Islam berserta cabang keilmuannya, akad perwakilan dikenal dengan istilah wakalah, akad perwakilan dalam sistem penggajian atau sistem payrol disebut wakalah bil ujrah. Maka hal demikian ini perlu di kuasai oleh dosen dan mahasiswa di fakultas ekonomi dan bisnis Islam. Demikian juga istilah-istilah yang digunakan dalam ilmu pendidikan, maka harus sering pula dikenalkan dengan istilahistilah dalam bahasa Arabnya, seperti tabiyah sendiri yang maknanya pengajaran. Pemanfaat pembiasaan bahasa Arab dari sisi fungsionalnya inilah yang perlu terus dilakukan dikuatkan pada setiap perguruan tinggi silam.

Upaya penguasaan dan pembiasaan istilah keilmuan dalam bahasa Arab ini juga merupakan sebuah upaya integrasi keilmuan. Padupadan yang dilakukan dari sisi bahasa ini sudah merupakan tuntutan zaman modern di tengah kuatnya wacara integrasi keilmuan. Sebagaimana menurut Ali Madkur, sebagaimana dikutip oleh Husen, dasar integrasi adalah pemikiran alamiah manusia cenderung untuk belajar sistimatik tematik terhadap berbagai aspek yang mungkin dipadu. $^{33}$ Tujuannya adalah untuk

32 Nazri Syakur, Revolusi Metodologi Pembelajan Bahasa Arab (Yogyakarta: BiPA, 2010).

33 Usman Husen, "Integrasi Bahasa Arab ke dalam Ilmu-ilmu Keislaman pada Prodi Pendidikan Agama Islam (PAI) FTK UIN Ar-Raniry," Lisanuna 5, mengaitkan pengalaman dengan fakta yang selalu terkait antara keduanya. Sebagai contoh sederhana, dosen sering menemukan mahsiswa telah memiliki banyak pengalaman tentang kaidah-kaidah nahwu dan saraf, namun mereka tetap menghadapi kesulitan ketika membaca kitab dan memahami maksud atau makna setiap kalimat. Kaidahkaidah nahwu yang telah dikuasai ataupun dihafal dengan baik tidak dapat diaplikasikan dalam menentukan baris kitab dan yang lebih utama dalam memahami teks. Padahal nahwu itu sendiri adalah aplikasi terhadap makna dalam stuktur kalimat dan itu pula dasar diceteuskan ilmu nahwu oleh Abu al-Aswad al-Duwali.

Model pembiasaan bahasa Arab untuk penguasan pada fungsionalnya dapat dilakukan dalam beberapa metode. Pertama, pembiasaan dalam kelas. Pembiasaan dalam kelas ini berlaku untuk pengajar dan juga mahasiswa. Para pengajar studi Islam atau di perguruan tinggi Islam perlu menggunakan istilah-istilah persamaan dalam bahasa Arab untuk setiap materi kuliah yang disampaikan. Sebagaimana diketahui, penggunaan istilah bahasa Inggris lebih umum digunakan daripada istilah bahasa Arab di perguruan tinggi Islam. Jikalau ditambah dengan istilah bahasa Arab berarti telah membiasan mahasiswa mengenal istilah yang khas studi Islam dan juga mengetahui istilah yang lumrah dalam bahasa Inggris sekaligus. Sedangkan pembiasaan dari mahasiswa juga merupakan hal yang sama, yakni perlu mencarikan dan menggunakan persamaan istilah dalam bahasa Arab untuk setiap makalah yang disampaikan. Pembiasaan ini akan mempermudah dalam memahami studi islam dan sekaligus dalam studi ilmu-ilmu umum. Di sinilah letak nilai integrasi keilmuan dari sisi bahasa dan hal ini pula yang menjadi nilai lebih pendidikan tinggi Islam dibanding dengan perguruan tinggi umum.

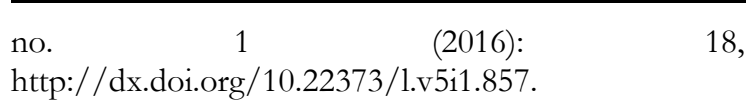


Kedua, pembiasaan dalam penulisan buku ajar, makalah ilmiah dan atau teks-teks kajian Islam lainnya. Dari sekian banyak buku dirasah islamiyah atau studi islam yang diterbitkan dalam bahasa Indonesia juga minim menggunakan istilah-istilah khusus dari bahasa Arab. Bahasa Inggris justru lebih banyak digunakan dalam padanan kata atau istilah ilmiah yang dipakai. Untuk membiasakan penggunakan istilah bahasa Arab dalam studi Islam, maka buku-buku ajar dan teks-teks terkait juga harus lebih membiasakan penggunanaan istilah bahasa Arab. Buku atau teks-teks pelajaran adalah jembatan ilmu pengetahuan yang paling penting dalam lintas generasi. Sehingga, apabila buku-buku kajian keislaman tetap mempertahankan istilah-istilah yang khusus berbahasa Arab, maka akan tetap digunakan pada generasi-generasi berikutnya. Hal ini sudah terbukti dengan karya-karya klasik yang mengadopsi istilah-istilah dari bahasa Latin dan Yunani. Misalnya saja kata philosophy menjadi falsafah yang sekarang juga diadopsi ke dalam bahasa Indonesia menjadi filsafat.

Ketiga, pembiasaan dalam forumforum ilmiah. Pembiasaan dalam forum ini memiliki tujuan sama yang dengan pembiasaan dalam kelas dan teks. Forum ilmiah bisa menjadi sarana untuk terus mengenalkan istilah-istilah khas kajian Islam, mulai dari makalah yang disajikan hingga paparan materinya. Bentuk pembiasaan yang sifatnya spontan ini mendukung pembiasaan yang sudah dilakukan pada tingkat kelas atau ruang pendidikan dan buku-buku referensi. Dengan demikian, maka penguatan istilahistilah dalam studi islam yang menggunakan bahasa Arab akan semakin mendapatkan tempat dan terus tersosialisasi dengan baik.

Uraian di atas memepertegah tentang pentingnya penguasaan bahasa Arab dalam kajian studi Islam. Bahasa Arab yang dulu menjadi bahasa ilmiah pada masa kejayaan Islam, perlu dihidupkan kembali supaya mendapatkan tempat yang layak dalam kajian ilmiah. Walaupun belum semua istilah bahasa Arab belum bisa digunakan dalam bahasa ilmiah, setidaknya sudah bisa diterapkan dan dipraktikan dalam studi Islam. Studi Islam yang tidak lagi menggunakan istilah-istilah bahasa Arab justru akan terasa janggal dan tidak bernafaskan Islam, bahkan bisa dikatakan hanya adopsi saja dari istilah-istilah ilmaiah yang sudah populer. Dengan pembiasaan dari sisi fungsional ini, istilah ilmiah dalam bahasa Arab bisa menjadi memberikan pembedaan kajian Islam dan sumbangsih Islam terhadap perkembangan ilmu pengetahuan. Sebagaimana hasil penelitian Miftah Wangsadanureja, dalam konteks ini, dapat ditegaskan bahwa bahasa arab mempunyai posisi sangat penting dan strategis dalam pengkajian dan pengembangan ilmu-ilmu keislaman, pengembangan peradaban Islam. ${ }^{34}$ Setidaknya, dari kupasan di atas dapat diketahui secara jelas perihal urgensi penguasaan istilah-istilah bahasa Arab dalam studi Islam.

\section{Penutup}

Penjelasan di atas telah menguraikan beberapa hal penting perihal urgensi penguasaan bahasa Arab bagi setiap pelajar dan juga pengajar di lingkungan pendidikan Islam. Harus diakui bahwa bahasa Arab memiliki karakteristik fungsional khusus yang tidak sama dengan bahasa pada umumnya. Karakter khusus itu yakni terletak pada bahasa sebagai bagain dari agama dan bahasa sebagai bagian dari ilmu pengetahuan. Sedangkan karakter universal yang terkandung dalam bahasa Arab yakni alat komunikasi. Fungsi yang khusus juga telah memberikan sumbangsih yang besar dalam sejarah peradaban Islam dan ilmu pengetahuan. Pada masa kejayaan Islam, bahasa Arab mampu menjadi bahasa resmi negara dan juga bahasa ilmiah ketika. Hal ini

34 Bandingkan dengan hasil penelitian Miftah yang menelaah silabus mata kuliah dalam penguatan bahasa Arab untuk studi Islam. Miftah Wangsadanureja, "Peran Bahasa Arab dalam Memahami Pendidikan Agama Islam dengan Pendekatan Berfikir," Jurnal Pendidikan Islam 8, no. 1 (2017): 16. 
terbukti dengan banyaknya karya-karya di luar bahasa Arab yang mampu diterjemahkan dengan baik dalam bahasa Arab ketika era Harun al-Rasyid hingga Al-Makmun.

Pengaruh bahasa Arab tidak hanya di jazirah Arab dan Timur Tengah. Di Nusantara, aksara Arab menjadi alat untuk menumpahkan kata-kata dalam bahasa Melayu yang ketika itu menjadi lingua franca sekaligus bahasa administrasi beberapa kerajaan. Maka tidak heran bila ada aksara Arab tetapi lafaznya melayu. Inilah yang kini dikenal dengan Arab pegon, tulisan Jawi dan juga Arab Melayu. Naskah-naskah klasik kerajaan Riau-Lingga dan kerajaan melayu umumnya menggunakan akasara Arab dengan bahasa Melayu. Hal ini mengindikasikan bahwa bahasa Arab telah menjadi bagian penting dalam tamadun dan intelektualisme Melayu. Era kerajaan hingga saat ini, mempelajari bahasa Arab juga adalah sebagai tujuan untuk bisa mengantarkan studi ke Timur Tengah. Sedangkan kajian Islam saat ini juga telah bertumbuh pesat seiring dengan bertambahnya pendidikan keagamaan formal, mulai dari tingkat madrasah hingga perguruan tinggi. Hal ini telah menjadi bukti perihal pentingnya penguasaan bahasa Arab dalam studi Islam.

Dari uraian di atas, dapat disimpulkan betapa secara fungsionalnya, bahasa Arab perlu dibiasakan oleh setiap pengajar, pelajar maupun pengkaji studi Islam agar eksistensi istilah-istilah ilmiah bahasa Arab tidak hilang. Untuk pembiasaannya, kesimpulan dalam artikel ini telah disebutkan perlu metode pembiasaan ketika berada di dalam kelas atau saat proses belajar dan mengajar, metode pembiasaan dalam penulisan karya buku ajar maupun teks-teks kajian studi Islam dan metode pembiasaan dalam forum-forum ilmiah. Pembiasaan atas fungsional bahasa Arab ini diharapkan bisa menumbuhkan istilah-istilah baru yang lebih representatif terhadap perkembangan ilmu pengetahuan. Dari penelitian ini pula penulis mengakui masih terdapat kelemahan dari sisi metode dan teori yang dikaji sehingga perlu dilakuan penelitian dengan metodologi yang berbeda guna mengetahui secara konfrehensip dari urgensi penguasaan istilah ilmiah dalam bahasa Arab.]

\section{DAFTAR PUSTAKA}

Alam Budi Kusuma. "Transformasi Pengajaran Bahasa Arab di Indonesia." Al-Manar 5, no. 1 (2016): 23.

Aly, Hery Nore. Ilmu Pendidikan Islam. Jakarta: Logos Wacana Ilmu, 2013.

Andriani, Asna. "Urgensi Pendidikan Bahasa Arab dalam Pendidikan Islam." Ta'allum 3, no. 1 (2015): 18. https://doi.org/10.21274/taalum.20 15.3.1.39-56.

Saragih, Amrin. Bahasa dalam Konteks Sosial. Medan: FBS Unimed, 2002.

Hamdun, Dudung. "Psikologi Belajar Bahasa." Al-Arabiyah 1, no. 2 (2006).

Husen, Usman. "Integrasi Bahasa Arab ke dalam Ilmu-ilmu Keislaman pada Prodi Pendidikan Agama Islam (PAI) FTK UIN Ar-Raniry." Lisanuna 5, no. 1 (2016): 18. http://dx.doi.org/10.22373/l.v5i1.85 7.

Tafsir, Ahmad. Ilmu Pendidikan Islam dalam Perspektif Islam. 9 ed. Bandung: PT Remaja Rosdakarya, 2010.

Mujib, Fathul. Rekonstruksi Pendidikan Bahasa Arab. Bandung: Pedagogia, 2010.

Nasution, S. Sejarah Pendidikan Idonesia. Jakarta: Bumi Aksara, 1995.

Nasution, Shkholid. Pengantar Linguistik Bahasa Arab. Malang: Lisanul Arabi, 2017.

Ridlo, Ubaid. "Bahasa Arab dalam Pusaran Arus Globalisasi: Antara Pesimisme dan Optimisme." Ibya' al-Arabiyab 01, no. 02 (2015): 17.

Salim, Latifah. "Sejarah Pertumbuha dan Perkembangan Bahasa Arab.” Diwan: Jurnal Babasa dan Sastra Arab 3, no. 1 (20 Juli 2017): 77. https://doi.org/10.24252/diwan.v3i1 .2928 . 
Saragih, Bahagia. "Linguistik Fungsional: Dimensi Dalam Bahasa." BAHAS 27, no. 03 (2016): 7. https://doi.org/10.24114/bhs.v27i3. 5672.

Syahid, Ahmad Habibi. "Bahasa Arab Sebagai Bahasa Kedua (Kajian Teoritis Pemerolehan Bahasa Arab pada Siswa Non-Native)." ARABIYAT: Jurnal Pendidikan Bahasa Arab dan Kebahasaaraban 2, no. 1 (12 September 2015). https://doi.org/10.15408/a.v2i1.179 7.

Syakur, Nazri. Revolusi Metodologi Pembelajan Bahasa Arab. Yogyakarta: BiPA, 2010.

Tohe, Achmad. "Bahasa Arab Fusha dan Amiyah serta Problematikanya." Babasa dan Seni 33, no. 2 (t.t.): 15.

Wahab, Muhbib Abdul. "Peran Bahasa Arab dalam Pengembangan Ilmu dan
Peradaban Islam." ARABIYAT: Jurnal Pendidikan Bahasa Arab dan Kebahasaaraban 1, no. 1 (2014). https://doi.org/10.15408/a.v1i1.112 7.

Wahyuni, Imelda. "Bahasa Arab dalam Konteks Simbol Agama (Analisis Terhadap Tujuan Pembelajaran pada Perguruan Tinggi Islam)." Zawiyah 3, no. 2 (2017): 15. http://dx.doi.org/10.31332/zjpi.v3i2 .720 .

Wangsadanureja, Miftah. "Peran Bahasa Arab dalam Memahami Pendidikan Agama Islam dengan Pendekatan Berfikir." Jurnal Pendidikan Islam 8, no. 1 (2017): 16.

Wekke, Islami Suardi. Pembelajaran Bahasa Arab di Madrasah. Yogyakarta: Deepublish, 2017. 